\title{
SATURDAY OF SCIENCE: A DAY IN ANTARCTICA - A SUCCESSFUL PARTNERSHIP BETWEEN "ESPAÇO CIÊNCIA VIVA" AND THE INCT-APA
}

\author{
Tais Maria de Souza Campos, Adriana Galindo Dalto, Rafael Bendayan de Moura, \\ Yocie Yoneshigue-Valentin
}

Laboratório de Macroalgas Marinhas, Departamento de Botânica, Instituto de Biologia, Universidade Federal do Rio de Janeiro - UFRJ, Av. Carlos Chagas Filho, 373, bloco A, sala A1-094, Ilha do Fundão, CEP 21941-902, Rio de Janeiro, RJ, Brazil

e-mail: taismaria@biologia.ufrj.br

https://doi.org/10.4322/apa.2016.020

Museums and science centers are important for dissemination and popularization of science, representing cultural spaces for knowledge construction (Paula et al., 2014). The "Espaço Ciência Viva" (ECV) or "Life Science Space" is considered one of the first participatory science museums in Brazil (Kurtenbach et al., 2004). This museum was founded by a group of scientists, researchers and educators who were interested in bringing science closer to people's everyday life. The ECV was created in 1982, in a $1600 \mathrm{~m}^{2}$ warehouse provided by the Government of the State of Rio de Janeiro, located at Saens Peña Square, in Tijuca. In contrast to formal museums, a sign at the entrance of the ECV ("Please, touch everything, but with care!") invites visitors to actively interact with science (Rubini et al., 2008) (Figure 1).

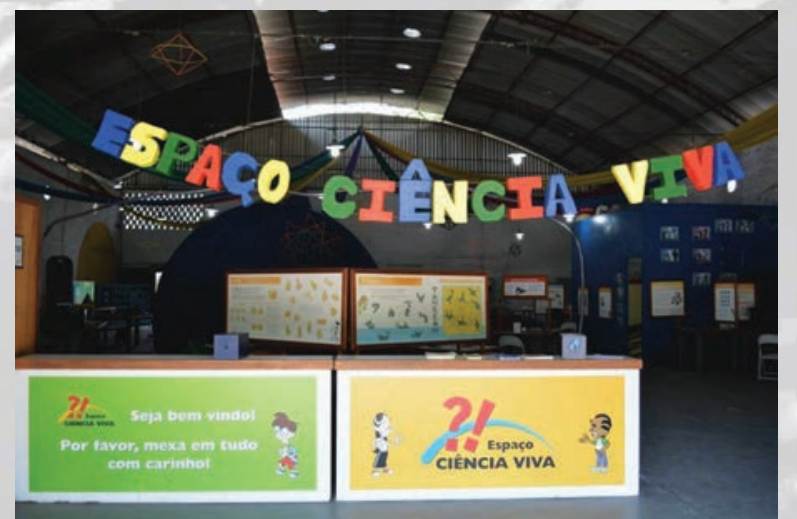

Figure 1. Main entrance to "Espaço Ciência Viva". Photo: Ciência Viva website.
The science museum "Espaço Ciência Viva" is part of the Rio de Janeiro Technology Network, the Latin American and Caribbean Network for the Popularization of Science (RedPop), and the Brazilian Association of Science Centers and Museums (ABCMC). ECV exhibitions are prepared in a way so that the public is able to participate in the activities and interact with material (Cavalcanti \& Persechini, 2011; Paula et al., 2014). The museum was created with the aim of actively disseminating science among visitors. This means that watching a demonstration, or listening or reading about a given subject is not enough; one must act and try to find the answers for the own questions.

The public of the science museum "Espaço Ciência Viva" is extremely diversified, including school groups from the most diverse regions of Rio de Janeiro, from elementary to high school students, young adults, people with special needs, local residents, undergraduate and graduate students, training teachers, and professionals from different areas.

On the last Saturday of each month, the museum opens with a specific event for the public called "Saturday of Science", which receives in average 300 visitors (Paula et al., 2014). The main topics covered by this event are related to health and environmental issues, which have been increasingly involving the academic community (Paula et al., 2014).

In partnership with the ECV, the National Institute of Science and Technology - Antarctic Environmental Research (INCT-APA) proposed, on August $30^{\text {th }}, 2014$, "A Day in Antarctica" as the main theme for the "Saturday of Science" initiative (Figure 2). 


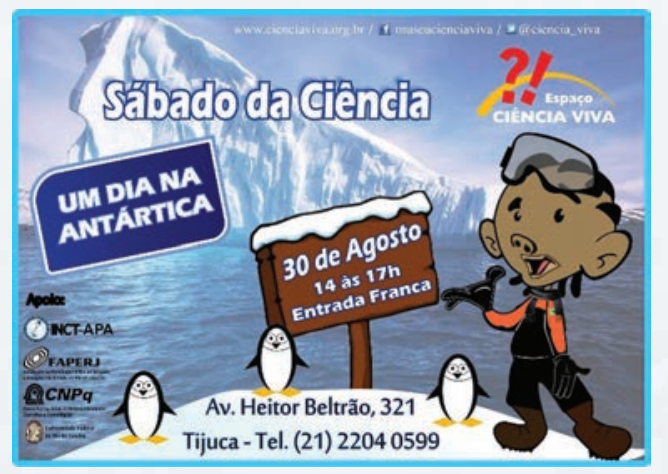

Figure 2. Flyer developed for the event, featuring one of the main characters of "Espaço Ciência Viva".

Several groups were involved in this event, including mediators from the ECV, INCT-APA researchers, the "Albatross" Navy Base Group of the "Comandante Ferraz" Brazilian Station in King George Island, Antarctica, and members of the Admiral Adalberto Nunes Physical Education Center (CEFAN), Admiral Átila Monteiro Aché Training Center (CIAMA), ${ }^{\text {st }}$ General Helicopter Squadron (HU-1) and the Center for Marine and Environmental Technology (NUTECMAR).

The "Saturday of Science" organized by "Espaço Ciência Viva" always counts on the participation of volunteers. These are mostly former interns, retired teachers and students who fulfill extracurricular activities. The INCT-APA has been represented by 13 researchers and seven assistants from the Federal University of Rio de Janeiro, who brought laboratory material and Antarctic algae and invertebrate specimens to the event. Prior to the realization of the event, some participants underwent a training process to make their workshops more dynamic and interactive with the public.

The event had 23 interactive activities that were presented in a general poster designed by mediators of the "Espaço Ciência Viva and placed at the main entrance of the ECV (Figure 3). These activities took place in a circuit of small stands, which had posters on various topics such as "Antártica or Antártida?" and "Why doesn't a polar bear eat penguins?"; workshops, such as "Robotics in Antarctica", "Electronic Instruments and Aviation", "Getting to Know Benthos", "Polychaete Power", "Crustaceans and the meiofauna", "Marine Phytoplankton", "Krill, what creature is this?", "Penguins and Skuas", "Facial Painting", "Comics", "Bacterial Biodiversity", "Magnetic Bacteria",
"Snow Crystals", "Origin and Formation of Ice Types" and "Cryosphere: UERJ in Antarctica"; demonstrations/ exhibitions of diving equipment used in Antarctica, "Electronic Instruments and Aviation", interactive games such as "Getting to Know Antarctica" and "Weddel Dive"; and "Physical Activities and Experiences in Antarctica". Furthermore, the public could attend two lectures, one by Dr. Yocie Yoneshigue-Valentin, coordinator of the INCTAPA, and the other by Márcio Arruda, the Lieutenant of the Brazilian Navy, and the presentation of a short video showing the routine of the base group and researchers at the Brazilian "Comandante Ferraz" Antarctic Station (Figure 4).

Approximately 900 people attended the ECV for the event during the three hours of activities. This corresponds to three times as many visitors as the number usually received by the ECV on Saturdays.

The partnership between the ECV and the INCT-APA allowed the public to have a better understanding of the Brazilian research developed in Antarctica through the several activities and exhibitions carried out during

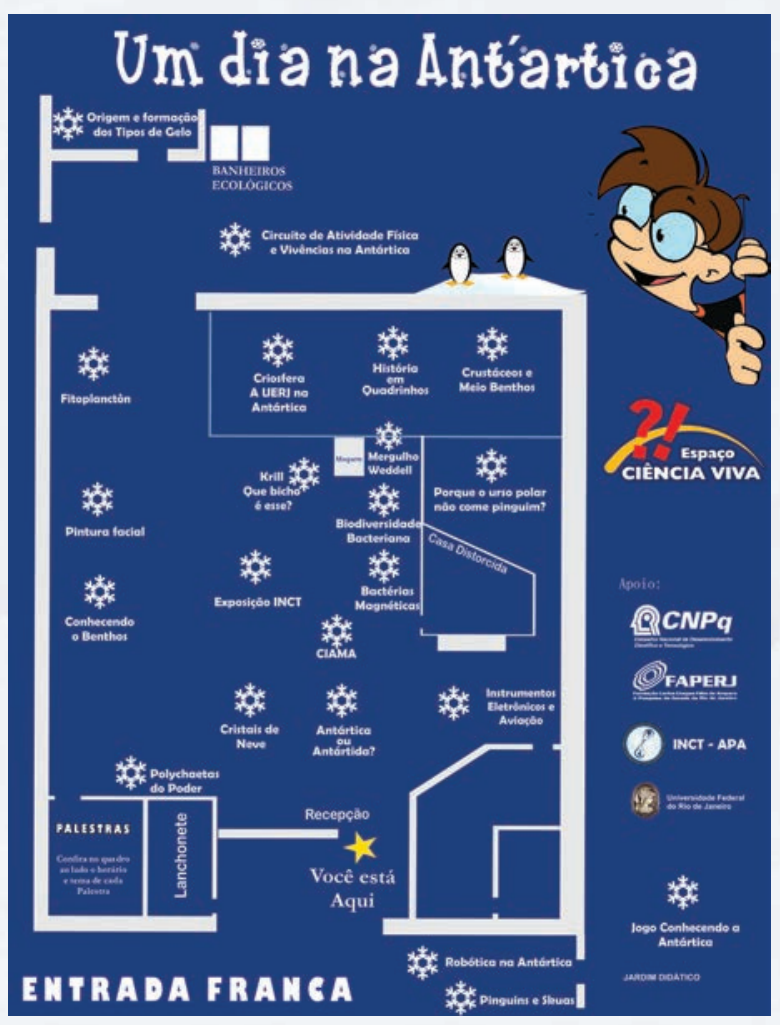

Figure 3. Poster showing all interactive activities offered during the event, designed by Amanda Ruiz (ECV). 

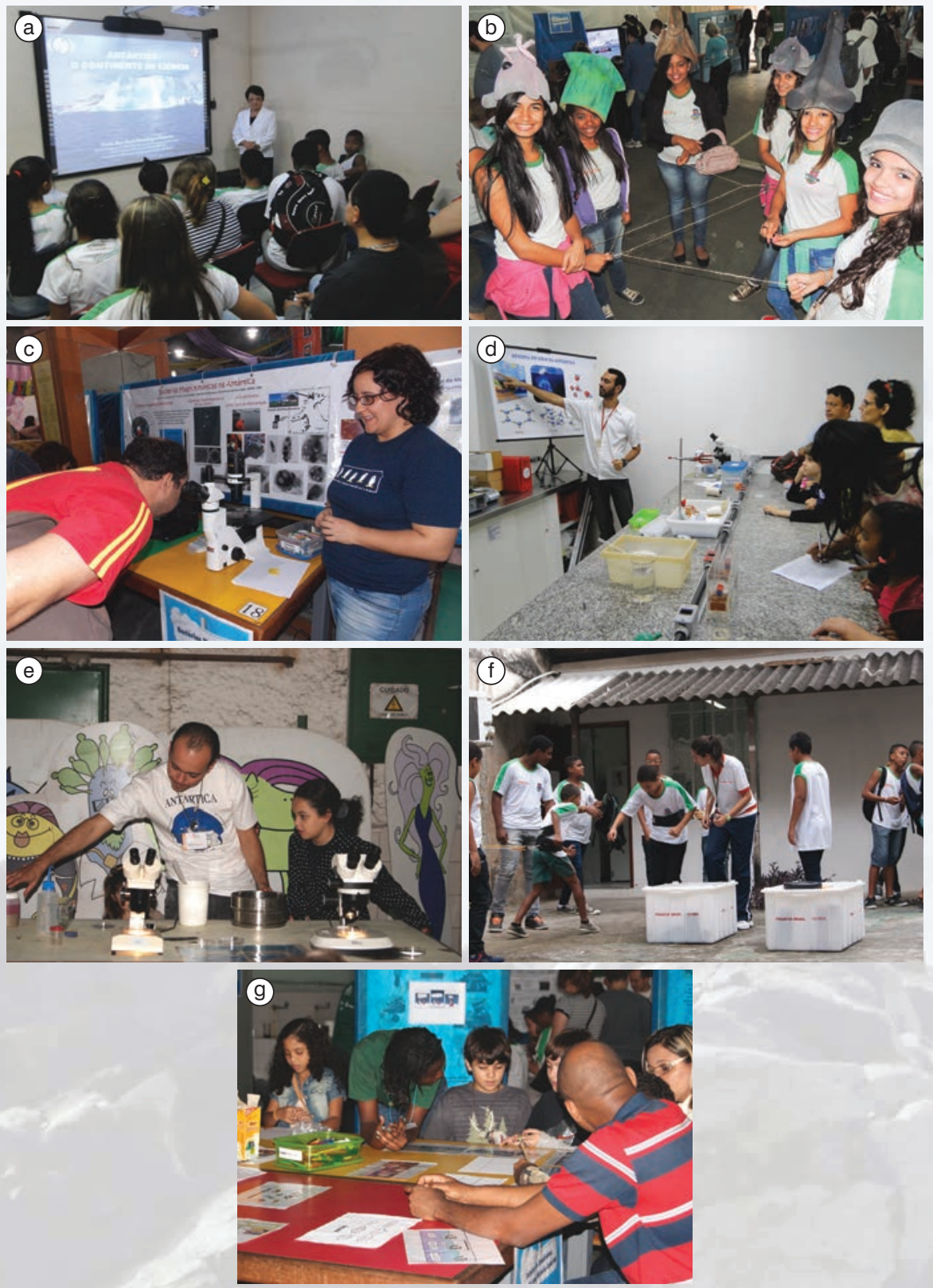

Figure 4. (A) Dr. Yocie Yoneshigue Valentin, coordinator of the INCT-APA, presenting a lecture on the Antarctic environment. (B) Playful representation of an Antarctic food web. (C) Workshop on magnetic bacteria. (D) Workshop on Antarctic ice. (E) Benthic meiofauna workshop. (F) Pre-Antarctic training activities (TPA) offered by Brazilian Navy officers. (G) Antarctic fauna comic strips drawing workshop. Photos: André Lanna, Jenifer Souza and Marcelle Araújo.

the event, taking science closer to society. The INCTAPA seeks an approximation between general public and researchers, raising awareness on the importance of Antarctica to the planet and to environmental issues related to the continent, as well as the popularization and dissemination of science.

\section{Acknowledgements}

This work is part of the National Institute of Science and Technology - Antarctic Environmental Research (INCT-APA) that receives scientific and financial support from the National Council for Research and Development (CNPq process: $n^{\circ}$ 574018/2008-5) and Carlos Chagas 
Research Support Foundation of the State of Rio de Janeiro (FAPERJ process: $n^{\circ}$ E-16/170.023/2008). The authors also acknowledge the support of the Brazilian Ministry of Science, Technology and Innovation (MCTI), Ministry of Environment (MMA), and Inter-ministry Comission for Sea Resources (CIRM). "Espaço Ciência Viva” is a nonprofit Civil Society organization registered in the Ministry of Finance under CNPJ n ${ }^{\circ}: 28.021426 / 0001-40$, and in the Civil Registry of Legal Entities under $n^{\circ} 10.4 .1983$. It is recognized as public utility by state law $n^{\circ} 560 / 90$ of 1990 . We thank "Espaço Ciência Viva" for the invitation and its employees, teachers and mediators for their collaboration. We thank all researchers and members of the Brazilian Navy for their commitment and dedication to the event.

\section{References}

Cavalcanti, C. B. \& Persechini, P. M. (2011) Science Museums and the Popularization of Science in Brazil. Field Actions Science Reports, Special Issue 3: 1-10.

Kurtenbach, E., Persechini, P. M., \& Coutinho-Silva, R. (2004). Espaço Ciência Viva: ciência e arte desde 1982. In T. C. A. Jorge (Org.), Ciência e arte: encontros e sintonias (pp.146-153). Rio de Janeiro: SENAC.

Paula, L. M., Ruiz, A. S., Pereira, G. R., Andrade, V. A., Coutinho-Silva, R., \& Kurtenbach, E. (2014). Um sábado de grandes descobertas: um olhar acerca dos sábados da Ciência do Espaço Ciência Viva no Rio de Janeiro. Latin American Journal of Science and Education, 1(22011), 1-14.

Rubini, G., Camanho, S. S., Bazin, M., Kurtenbach, E., \& Coutinho-Silva, R. (2008). A maneira de receber o público no Espaço Ciência Viva. In L. Massarani \& C. Almeida (Eds.), Workshop Sul-Americano \& Escola de Mediação em Museus e Centros Ciência (pp. 57-62). Rio de Janeiro: Museu da Vida, Casa de Oswaldo Cruz-Fiocruz. 144 p. 